\title{
BmARM-Like Protein from Silkworm, Bombyx mori (Lepidoptera) is Putatively Involved in Response against BmNPV Infection
}

\author{
Xue-yang Wang ${ }^{1}$, Shang-zhi Zhang ${ }^{1}$, Ming-hui Liu ${ }^{2}$, Dong Yu' ${ }^{1}$, Yan Ma ${ }^{1}$, \\ Dong-qiong $\mathrm{Fei}^{1}$, Hai-zhong $\mathrm{Yu}^{1}$ and Jia-ping $\mathrm{Xu}^{1}{ }^{1 *}$ \\ ${ }^{1}$ School of Life Sciences, Anhui Agricultural University, 130 West Changjiang Road, \\ Hefei, 230036, People's Republic of China \\ ${ }^{2}$ Institute of Sericulture, Anhui Academy of Agricultural Sciences, 15 Huoshan Road, \\ Hefei, 230061, People's Republic of China
}

\begin{abstract}
A B S T R A C T
Armadillo (ARM)-repeat protein is involved in many biological processes, including cell-cell adhesion and the Wnt signaling pathway. However, the function of ARM-repeat protein in Bombyx mori has not been completely clarified. In this study, a gene encoding ARM-repeat protein was identified, which has an open reading fragment of $1923 \mathrm{bp}$, encoding a predicted 641 amino acid residues with a molecular weight of approximately $71.2 \mathrm{kDa}$. BmARM-like mRNA showed highest expression in hemolymph, significantly high expression levels in $4^{\text {th }}$ instar, moth, and egg, stable high expression levels in the early embryonic development, relatively high expression levels in the $1^{\text {st }}$ day and $5^{\text {th }}$ day of the pupa stage, and highest expression levels in the molting stage. What's more, BmARM-like protein could be detected by immunofluorescence in all analyzed tissues, including head, midgut, hemolymph, fat body, testis and ovary. More importantly, the relatively high expression level of BmARM-like mRNA were observed in BC9 (near-isogenic line) following BmNPV infection as compared to P50 (susceptible strain), which was further validated in the midgut of A35 (resistant strain). The expression levels of BmARM-like protein showed similar trends with transcriptional levels in the midgut following BmNPV infection. Based on the analysis above, we speculated that BmARM-like is involved in response against BmNPV infection.
\end{abstract}
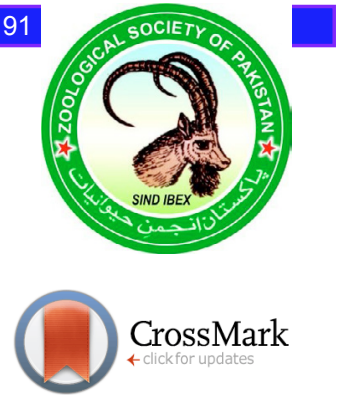

Article Information

Received 07 October 2016

Revised 17 November 2016

Accepted 24 December 2016

Available online 21 November 2017

Authors' Contributions

JPX conceived and designed the experiments. XYW, SZZ, DY, DQF, and YM performed the experiments. XYW and JPX analysed the data and wrote the manuscript. HZY and MHL helped in experimental work.

\section{Key words}

Bombyx mori, Nucleopolyhedrovirus (NPV), Embryonic development, Response against NPV infection.

\section{INTRODUCTION}

A rmadillo (ARM)-repeat proteins are characterized by approximately 42 amino acid motifs called ARM domains, which are composed of three $\alpha$-helices (Peifer et al., 1994; Schwede et al., 2003; Zhang et al., 2011). The crystal structures of numerous ARM-repeat proteins demonstrate that although ARM-repeat proteins do not necessarily share a great deal of sequence identity (Huber et al., 1997; Choi and Weis, 2005; Kidd et al., 2005; Liu et al., 2008; Striegl et al., 2010), they do share a relevant structure and are evolutionarily ancient (Tewari et al., 2010). Besides, ARM-repeat units tandem fold together forming a superhelix that provides a versatile platform for interacting with other protein partners (Coates, 2003; Liu et al., 2008; Zhao et al., 2009; Striegl et al., 2010).

$\beta$-catenin was initially discovered in the early 1990 s as a component of mammalian cell adhesion complexes

\footnotetext{
* Corresponding author: jiapingxu@163.com 0030-9923/2016/0006-2181 \$ 9.00/0 Copyright 2017 Zoological Society of Pakistan
}

(McCrea et al., 1991). Subsequently, the Drosophila protein armadillo was identified as a homolog of $\beta$-catenin, not just in structure but also in function (Kemler, 1993). $\beta$-catenin (Armadillo in Drosophila), which is the prototypical ARM-repeat protein, is a fascinating protein with many important cellular and developmental functions (Tewari et al., 2010). $\beta$-catenin has two main functions linking cell-adhesion molecules to the cytoskeleton and participating in the Wnt signaling pathway (Noordermeer et al., 1994; Behrens et al., 1996; Brembeck et al., 2006). $\beta$-catenin is also part of the protein complex that forms adherens junctions, which are important for cell adhesion and thus essential for the formation of complex tissues (Ozawa et al., 1989; Aberle et al., 1994; Brembeck et al., 2006). In the canonical Wnt signaling pathway, $\beta$-catenin is one of the most important nods and is involved in the control of cell fate, tissue homeostasis, and a variety diseases (Noordermeer et al., 1994; MacDonald et al., 2009). In this pathway, the stabilized cytoplasmic $\beta$-catenin can enter into the nucleus where it can interact with T-cell factor/lymphoid enhancer-binding factor DNA binding proteins to initiate transcription of a target gene(s) (Tolwinski 
and Wieschaus, 2001; Mosimann et al., 2006).

Recently, several studies have made significant progress in determining the function of the ARMrepeat protein. Smith et al. (2005) reported that the armadillo-related gene Alex2, played an important role in specification or development of the interstitial cell lineage. Ngo et al. (2012) reported that plant ARM-repeat proteins were involved in promoting early seed growth through a distinct gametophytic maternal effect of zak ixik. Coates et al. (2006) reported that Arabidopsis 13-catenin-related proteins defined a previously uncharacterized pathway that promotes root branching. Rhee et al. (2006) reported that the expression of $\beta$-catenin significantly increased in mouse osteoblastic MC3T3-E1 cells after exposure to parathyroid hormone.

Additionally, ARM-repeat proteins have been reported to be involved in the anti-pathogen response of several organisms. Couillault et al. (2004) reported that armadillo motif-containing protein (SARM) was crucial for the Caenorhabditis elegans immune response against bacterial and fungal infection. Wang et al. (2013) reported that the expression of SARM in Litopenaeus vannamei was responsive to Vibrio alginolyticus and white spot syndrome virus infection in different tissues. Liu et al. (2014) reported that the anti-inflammatory effects of resveratrol were developed by up-regulating sterile alpha and armadillo motif protein in the 9HTEo mice cell line after infection with respiratory syncytial virus.

An armadillo homolog protein in silkworm has been found to be localized in a segmentally reiterated striped pattern, in conformity with its predicted segment polarity nature (Dhawan and Gopinathan, 2004). In this study, we have identified a $71 \mathrm{kDa}$ protein containing an armadillo repeat, which we have named BmARM-like protein. Herein, we carried out molecular characterization and functional analysis of BmARM-like protein in silkworms. RT-qPCR was used to analyze the expression patterns of BmARM-like mRNA in different tissues, at developmental stages, and in different resistant silkworm strains following BmNPV infection. Tissue localization of BmARM-like protein was also determined using immunofluorescence.

\section{MATERIALS AND METHODS}

\section{Silkworm and BmNPV}

The susceptible strain P50, the resistant strain A35 and the near-isogenic line BC9 (Wang et al., 2016) were maintained in the Key Laboratory of Sericulture, School of Life Sciences, Anhui Agriculture University, Heifei, China. Silkworms, Bombyx mori (Lepidoptera) were reared according to the method described by Wang et al. (2016). The BmNPV T3 strain was maintained in our laboratory, and was purified by repeated and differential centrifugation according to the protocol developed by Rahman and Gopinathan (2004).

\section{Sample preparation}

Silkworms at the first day of the $5^{\text {th }}$ instar were fed with $5 \mu \mathrm{L}$ BmNPV $\left(1.0 \times 10^{5} \mathrm{OB} / \mathrm{mL}\right)$ per larvae. Thirty larvae, pupa or moths were mixed together to minimize individual genetic differences. Eggs from one egg batch were scraped and mixed together. All samples were frozen immediately in liquid nitrogen and stored at $-80{ }^{\circ} \mathrm{C}$ or immersed in $4 \%$ paraformaldehyde directly and stored at $4{ }^{\circ} \mathrm{C}$.

\section{Bio-information analysis, cloning and sequencing}

The functional domain of BmARM-like was predicted using online software (http://www.ncbi.nlm.nih.gov/ Structure/cdd/wrpsb.cgi). The theoretical molecular weight $(\mathrm{MW})$ and isoelectric point $(\mathrm{P} I)$ were calculated using PeptideMass (http://web.expasy.org/peptide_mass/). Homology alignment and phylogenetic tree construction were carried out using DNAMAN (Version 6.0.40) and MEGA 5 (Version 5.2), respectively.

RNA extraction and the first strand cDNA synthesis were carried out according to the protocol by Wang et al. (2016). The functional domain of BmARM-like was amplified by polymerase chain reaction (PCR) using specific primers (Table 1). The PCR product was cloned into the pMD19-T vector and then transferred into $E$. coli competent cells (Trans $5 \alpha$ ) for sequencing.

\section{Real-time quantitative PCR (RT-qPCR)}

RT-qPCR was used to analyze the expression patterns of BmARM-like mRNA. The primer sequences are listed in Table 1. RT-qPCR was carried out according to the protocol outlined by Wang et al. (2016). B. mori glyceraldehyde3-phosphate dehydrogenase (BmGAPDH) was used as an internal control. The relative expression levels were calculated using the $2^{-\Delta \Delta C T}$ method following the protocol used by Livak and Schmittgen (2001). Statistical analysis was conducted using SPSS software (IBM, USA).

\section{Polyclonal antibody preparation}

The recombinant plasmid pET-28a-BmARMlike was induced to express the fusion protein of the functional domain of BmARM-like protein at an $\mathrm{OD}_{600}$ of 0.5 by adding isopropyl thiogalactoside (IPTG; final concentration $0.2 \mathrm{mM}$ after optimization) at $16{ }^{\circ} \mathrm{C}$ for $24 \mathrm{~h}$ and then purified using the high affinity Ni-NTA resin (GenScript, China) according to the manufacturer's instructions. The level of expression of the fusion protein 
Table I.- The primers used in RT-qPCR and the functional domain amplification.

\begin{tabular}{lll}
\hline Gene name & Forward primers $\mathbf{( 5 '}$ - 3') & Reverse primers $\mathbf{( 5 '}$ - 3') \\
\hline BmARM-like & GAGAATGCGGTTCAAACGATA & AAATAGCAGGTCAACGGTGTCA \\
BmGAPDH & CCGCGTCCCTGTTGCTAAT & CTGCCTCCTTGACCTTTTGC \\
$\begin{array}{l}\text { The functional domain } \\
\text { of } B m A R M \text {-like }\end{array}$ & CCGGAATTCATGGGTAAGGTTCGAAAAA, & CCGCTCGAGTTAAGAGTTGAGAGGGGTCA, \\
\hline
\end{tabular}

was evaluated by $12 \%$ SDS-PAGE and the concentration of fusion protein was quantified using the Bradford method (Bradford, 1976).

The New Zealand white rabbit was injected intraperitoneally with $1.0 \mathrm{~mL}$ mixture of $1.0 \mathrm{mg}$ purified fusion protein and Freund's complete adjuvant (Sigma, USA). The immunity was boosted three times with 0.5 $\mathrm{mg}$ fusion protein in Freund's incomplete adjuvant at one week intervals. Serum was collected after the last injection. The elution buffer $(0.09 \mathrm{mM} \mathrm{NaHCO}, 0.3 \mathrm{mM} \mathrm{NaCl}$, $0.25 \mathrm{mM} \mathrm{C}_{3} \mathrm{H}_{4} \mathrm{~N}_{2}, \mathrm{pH} 8.0$ ) was used as a negative control. Indirect ELISA was used to detect the titer of polyclonal antibodies in the serum. The remaining serum was stored at $-80{ }^{\circ} \mathrm{C}$ for later use.

\section{Tissue protein extraction}

All tissues were ground to powder in liquid nitrogen and suspended in extraction buffer $(50 \mathrm{mM}$ Tris- $\mathrm{Cl} \mathrm{pH}$ $8.0,150 \mathrm{mM} \mathrm{NaCl}, 1.0 \mathrm{mM}$ EDTA, $1 \% \mathrm{NP}-40,1.0 \mathrm{mM}$ PMSF), then kept on ice for $30 \mathrm{~min}$. The homogenates were centrifuged at $12,000 \mathrm{rpm}$ for $5 \mathrm{~min}$ at $4{ }^{\circ} \mathrm{C}$. The supernatants were collected and total protein was quantified by the Bradford method.

\section{Western blotting}

The protein samples were lysed in $5 \times$ protein loading buffer (50 mM Tris- $\mathrm{HCl} \mathrm{pH} 8.0,250 \mathrm{mM}$ DTT, $5 \%$ SDS, $50 \%$ glycerol, $0.04 \%$ Bromophenol Blue) and then boiled for $10 \mathrm{~min}$. The samples were separated by $12 \%$ SDS-PAGE and transferred onto polyvinylidene fluoride (PVDF) membranes (Roche, Switzerland). Subsequently, the membranes were blocked with 5\% nonfat milk in $0.01 \mathrm{M}$ phosphate-buffered saline (PBS; $10 \mathrm{mM} \mathrm{Na}_{2} \mathrm{HPO}_{4}, 1.8 \mathrm{mM} \mathrm{KH}_{2} \mathrm{PO}_{4}, 140 \mathrm{mM} \mathrm{NaCl}, 2.7$ $\mathrm{mM} \mathrm{KCl} \mathrm{pH} \mathrm{7.4)} \mathrm{at} \mathrm{room} \mathrm{temperature} \mathrm{(RT)} \mathrm{for} 1 \mathrm{~h}$, then incubated with rabbit serum $(1: 10,000)$ at RT for $1 \mathrm{~h}$. After washing with PBST (PBS $+0.05 \%$ Tween-20) three times, the membranes were incubated with HRP-conjugated goat anti-rabbit IgG (1:10,000; TransGen biotech, China) at RT for $1 \mathrm{~h}$, washed three times in PBST and visualized using a diaminobenzidine (DAB) Kit (TIANGEN, China) according to the manufacturer's instructions. $\beta$-actin was used as a loading control. Anti- $\beta$-actin mouse monoclonal antibody and HRP-conjugated goat anti-mouse IgG (TransGen biotech, China) were diluted as per the manufacturer's instructions.

\section{Immunofluorescence}

All the tissues fixed in 4\% paraformaldehyde were dehydrated and embedded in paraffin. Tissue sections (4 $\mu \mathrm{m}$ thick) were transferred to microscope slides and then deparaffined and rehydrated. Subsequently, sections were treated with transparent buffer (PBS containing $0.3 \%$ hydrogen peroxide and $0.3 \%$ Triton $\mathrm{X}-100$ ) at RT for 30 min, washed three times in PBS, and then incubated with $0.01 \mathrm{M}$ citrate buffer $\left(5 \mathrm{mM} \mathrm{C}_{6} \mathrm{H}_{8} \mathrm{O}_{7}, 24\right.$ $\mathrm{mM} \mathrm{Na}{ }_{3} \mathrm{C}_{6} \mathrm{H}_{5} \mathrm{O}_{7} \cdot 2 \mathrm{H}_{2} \mathrm{O}, \mathrm{pH} 6.0$ ) at $96{ }^{\circ} \mathrm{C}$ for $15 \mathrm{~min}$. After washing three times with PBS, sections were blocked with $10 \%$ goat serum for $30 \mathrm{~min}$, then incubated with rabbit serum $(1: 100)$ at $\mathrm{RT}$ for $1 \mathrm{~h}$, then at $4{ }^{\circ} \mathrm{C}$ overnight followed by $37{ }^{\circ} \mathrm{C}$ for $45 \mathrm{~min}$. Following washing five times in PBST, sections were incubated with anti-rabbit IgG conjugated with FITC (1:100; TransGen biotech, China) at $37^{\circ} \mathrm{C}$ for $30 \mathrm{~min}$, washed three times in PBST, and then incubated with 4,6-diamidino-2-phenylindole (DAPI, 1:1000; FanBo, China) at RT for 2 min. After washing with PBST three times, images were obtained using a fluorescence microscope (Olympus BX51, Japan).

\section{RESULTS}

\section{Sequence analysis of BmARM-like}

The full length of BmARM-like was obtained from the silkworm genome database (http://www.silkdb.org/ silkdb/). The GenBank accession number for BmARMlike is JF500112. BmARM-like consists of a $97 \mathrm{bp}$ 5'-untranslated region (5'-UTR), 140 bp 3'-UTR and $1923 \mathrm{bp}$ open reading fragment (ORF) which encodes a polypeptide with 641 amino acid residues (Fig. 1). The theoretical $\mathrm{MW}$ and $\mathrm{p} I$ are $71.2 \mathrm{kDa}$ and 4.76 , respectively.

In searching GenBank, homologs of BmARM-like protein were found in many insects, including Papilio xuthus (KPI94899.1), Papilio Machaon (XP_014368349.1), Amyelois transitella (XP_013191284.1),Plutellaxylostella(XP_011560493.1), Danaus plexippus (EHJ73656.1), Operophtera brumata 
1 taaatgaatttgaaacgtaatggcaatagataaaattctgcaatgatacacaacataaatgttaaaaataaattgattaataggttacaa 92 gcgaa atgggtaaggttcgaaaactaaggctcgtaaagtcaaaacgctgtggttagcgaagagagcaatgaagaagagcaactttcaaat 184 $\begin{array}{lllllllllllllllllllllllllllllll}M & G & K & V & R & K & T & K & A & R & K & V & K & N & A & V & V & S & E & E & S & N & E & E & E & Q & L & S & N & 29\end{array}$ gatagcaaagagaatgcggttcaaacgatattagatcagttgcagggagcaagtgttgaagagaagtattgcggtttgcaaactttggca 274 $\begin{array}{llllllllllllllllllllllllllllllll}\mathrm{D} & \mathrm{S} & \mathrm{K} & \mathrm{E} & \mathrm{N} & \mathrm{A} & \mathrm{V} & \mathrm{Q} & \mathrm{T} & \mathrm{I} & \mathrm{L} & \mathrm{D} & \mathrm{Q} & \mathrm{L} & \mathrm{Q} & \mathrm{G} & \mathrm{A} & \mathrm{S} & \mathrm{V} & \mathrm{E} & \mathrm{E} & \mathrm{K} & \mathrm{Y} & \mathrm{C} & \mathrm{G} & \mathrm{L} & \mathrm{Q} & \mathrm{T} & \mathrm{L} & \mathrm{A} & 59\end{array}$ atgtttatagagattccagagaatatgatgaagttataaaccagggtcttgtaaaagttgctgctcctttattgctggatcctgctagt 364

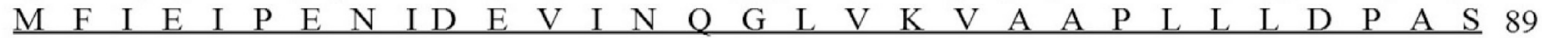
tctgtgagaatgcatcatctggtatgcttcgaaatctatctgctgttaagctggatattgtgattctctgatggatcaggatattatg 454 \begin{tabular}{llllllllllllllllllllllllllllllll}
\hline & \multicolumn{1}{ll}{} & $\mathrm{V}$ & $\mathrm{R}$ & $\mathrm{N}$ & $\mathrm{A}$ & $\mathrm{S}$ & $\mathrm{S}$ & $\mathrm{G}$ & $\mathrm{M}$ & $\mathrm{L}$ & $\mathrm{R}$ & $\mathrm{N}$ & $\mathrm{L}$ & $\mathrm{S}$ & $\mathrm{A}$ & $\mathrm{V}$ & $\mathrm{K}$ & $\mathrm{L}$ & $\mathrm{D}$ & $\mathrm{I}$ & $\mathrm{C}$ & $\mathrm{D}$ & $\mathrm{S}$ & $\mathrm{L}$ & $\mathrm{M}$ & $\mathrm{D}$ & $\mathrm{Q}$ & $\mathrm{D}$ & $\mathrm{I}$ & $\mathrm{M}$ & 119
\end{tabular} acaccgttgacctgctatttcatgaacatgcagaatcatggatacctgatccaattctaaatcaagagatgaagatatgatacatt 544 \begin{tabular}{llllllllllllllllllllllllllllllll}
\hline & P & L & T & C & Y & F & H & E & H & A & E & S & W & I & P & D & P & I & S & $K$ & S & $R$ & $D$ & $E$ & $D$ & I & D & T & F & 149
\end{tabular} gttcaatgtgttaattgttgttgaattgtgtgaaagttctgacttagctgttaa tatgttggtcaatctaggatactagatatactt 634 $\begin{array}{llllllllllllllllllllllllllllllll}\mathrm{V} & \mathrm{Q} & \mathrm{C} & \mathrm{V} & \mathrm{N} & \mathrm{L} & \mathrm{L} & \mathrm{L} & \mathrm{N} & \mathrm{L} & \mathrm{C} & \mathrm{E} & \mathrm{S} & \mathrm{S} & \mathrm{D} & \mathrm{L} & \mathrm{A} & \mathrm{V} & \mathrm{K} & \mathrm{Y} & \mathrm{V} & \mathrm{G} & \mathrm{Q} & \mathrm{S} & \mathrm{R} & \mathrm{I} & \mathrm{L} & \mathrm{D} & \mathrm{I} & \mathrm{L} & 179\end{array}$ ccaagatacttagatatgtcattattggtatagacatagtagcagcagtactgcaatgcetgtttgttgttgttgaagacaatccactt 724

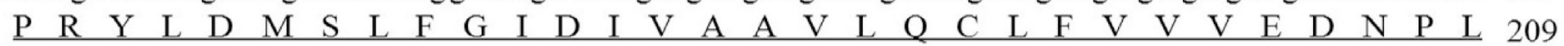
gcaatggaaaaatcaaatcaaattgtcaaaacagctacaactttaatctatctggaaggaactgaccctctcaactcttaattaaa 814

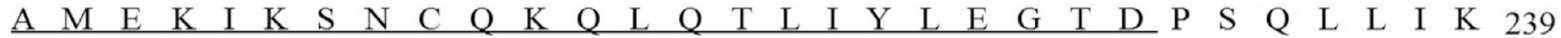
acattatctgetggagttataataatacacatggaggcaacttacaaccttacctattgaaatgataatcaaataatgtctatacta 904 $\begin{array}{llllllllllllllllllllllllllllllll}\mathrm{T} & \mathrm{L} & \mathrm{S} & \mathrm{A} & \mathrm{G} & \mathrm{V} & \mathrm{I} & \mathrm{I} & \mathrm{N} & \mathrm{T} & \mathrm{H} & \mathrm{G} & \mathrm{G} & \mathrm{K} & \mathrm{L} & \mathrm{T} & \mathrm{T} & \mathrm{L} & \mathrm{P} & \mathrm{I} & \mathrm{E} & \mathrm{M} & \mathrm{I} & \mathrm{N} & \mathrm{Q} & \mathrm{I} & \mathrm{M} & \mathrm{S} & \mathrm{I} & \mathrm{L} & 269\end{array}$ gcaaagactttatcagtggatcataggtttgcttgcaatcagttgtcaagtcaagttccattgaaaatacttctggaagatggaggac 994

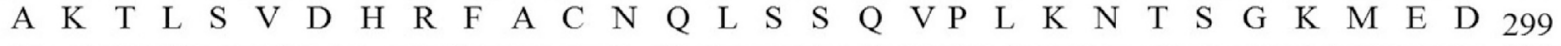
ccacctaaaattaaagatgcgcaaatattagacaaacaaattaaggcagtcattcaaatgctggatgcccaacaaagtgctattgaaatc 1084

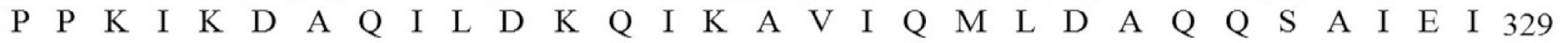
attgctaacatttgttcagatgaagatggcgatgatatca atagtgatagctcttctgaaataatgaaattgatgaagaaattgtcag 1174 $\begin{array}{llllllllllllllllllllllllllllllll}\text { I } & A & N & I & C & \text { S } & D & E & D & G & D & D & I & N & S & D & S & S & S & E & N & N & E & I & D & E & E & I & C & Q & 359\end{array}$ aatggaaatggtacactcctcacagaagataaacttcctccagaagtcttggaagcattagtgaatttgaagtattcaaagagtatgg 1264

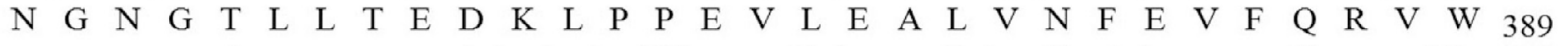
gcaagaacagaatgccagcccaaatgtagtcatgatttaaaagattatgaaggttctcaattgatatgcaaaaattacagagttta 1354 $\begin{array}{llllllllllllllllllllllllllllllll}\text { A } & R & T & \text { E } & M & \text { P } & \text { A } & \text { Q } & \text { N } & \text { V } & \text { V } & \text { M } & \text { I } & \text { L } & \text { K } & \text { D } & \text { Y } & \text { E } & \text { G } & \text { S } & \text { Q } & \text { L } & \text { I } & \text { C } & \text { K } & \text { K } & \text { L } & \text { Q } & \text { S } & \text { L } & 419\end{array}$ caacgagagctctactgtgtgttaacaatatgatatcttcactaccaaatgcgagtcttggaggtgttaatggtatctataaatctgg 1444 $\begin{array}{lllllllllllllllllllllllllllllll}\mathrm{Q} & \mathrm{T} & \mathrm{R} & \mathrm{A} & \mathrm{L} & \mathrm{L} & \mathrm{C} & \mathrm{V} & \mathrm{N} & \mathrm{N} & \mathrm{M} & \mathrm{I} & \mathrm{S} & \mathrm{S} & \mathrm{L} & \mathrm{P} & \mathrm{N} & \mathrm{A} & \mathrm{S} & \mathrm{L} & \mathrm{G} & \mathrm{G} & \mathrm{V} & \mathrm{N} & \mathrm{G} & \mathrm{I} & \mathrm{Y} & \mathrm{K} & \mathrm{I} & \text { W } & 449\end{array}$ gtggatgcaggaaattagtattcaaacaaagagaagaaatttaaatctcttagaatctgctacagcagtgatgagagctgcactagat 1534 $\begin{array}{llllllllllllllllllllllllllllllll}\mathrm{V} & \mathrm{D} & \mathrm{A} & \mathrm{G} & \mathrm{K} & \mathrm{L} & \mathrm{V} & \mathrm{F} & \mathrm{K} & \mathrm{Q} & \mathrm{R} & \mathrm{E} & \mathrm{E} & \mathrm{N} & \mathrm{L} & \mathrm{N} & \mathrm{L} & \mathrm{L} & \mathrm{E} & \mathrm{S} & \mathrm{A} & \mathrm{T} & \mathrm{A} & \mathrm{V} & \mathrm{M} & \mathrm{R} & \mathrm{A} & \mathrm{A} & \mathrm{L} & \mathrm{D} & 479\end{array}$ aaa taa acttagagacagtgataaagctagtgatattagcttattcaatgatctggccatctctgatatagaaattatgttaactgga 1624 $\begin{array}{lllllllllllllllllllllllllllllll}\text { K } & \text { I } & \text { K } & \text { L } & \text { R } & \text { D } & \text { S } & \text { D } & \text { K } & \text { A } & \text { S } & \text { D } & \text { I } & \text { S } & \text { L } & \text { F } & \text { N } & \text { D } & \text { L } & \text { A } & \text { I } & \text { S } & \text { D } & \text { I } & \text { E } & \text { I } & \text { M } & \text { L } & \text { T } & \text { G } & 509\end{array}$ atcagacaatgtgaagtgcctgagataaggtcaaacctaatacgaatggtcggtatacttgccctattattggtaaacaacttgaatgac 1714 $\begin{array}{llllllllllllllllllllllllllllllll}\mathrm{I} & \mathrm{R} & \mathrm{Q} & \mathrm{C} & \mathrm{E} & \mathrm{V} & \mathrm{P} & \mathrm{E} & \mathrm{I} & \mathrm{R} & \mathrm{S} & \mathrm{N} & \mathrm{L} & \mathrm{I} & \mathrm{R} & \mathrm{M} & \mathrm{V} & \mathrm{G} & \mathrm{I} & \mathrm{L} & \mathrm{A} & \mathrm{L} & \mathrm{L} & \mathrm{L} & \mathrm{V} & \mathrm{N} & \mathrm{N} & \mathrm{L} & \mathrm{N} & \mathrm{D} & 539\end{array}$ atcacttctaatgtgattgcaccatcacagattcataatagaacaatcacacaaagagaatgaagtatgggtgctggcegaggcacta 1804 $\begin{array}{llllllllllllllllllllllllllllllll}\mathrm{I} & \mathrm{T} & \mathrm{S} & \mathrm{N} & \mathrm{V} & \mathrm{I} & \mathrm{C} & \mathrm{T} & \mathrm{I} & \mathrm{T} & \mathrm{D} & \mathrm{F} & \mathrm{I} & \mathrm{I} & \mathrm{E} & \mathrm{Q} & \mathrm{S} & \mathrm{H} & \mathrm{K} & \mathrm{E} & \mathrm{N} & \mathrm{E} & \mathrm{V} & \mathrm{W} & \mathrm{V} & \mathrm{L} & \mathrm{A} & \mathrm{E} & \mathrm{A} & \mathrm{L} & 569\end{array}$ gatacttggtagatttatatgctgaagatgaaacagattatttagctgctaaagtgaaactagttgacaagttggcgatactggcacca 1894

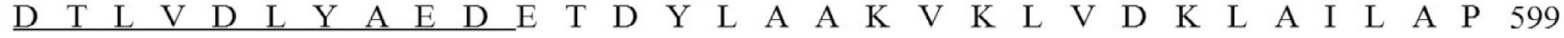
atttaaagaataaggetagacagcaaaagagacttccaaagaatacaaagttctcgtcaatactgegatcactaatttaccgagattt 1984 $\begin{array}{llllllllllllllllllllllllllllllllll}\text { I } & \mathrm{L} & \mathrm{K} & \mathrm{N} & \mathrm{K} & \mathrm{A} & \mathrm{R} & \mathrm{Q} & \mathrm{Q} & \mathrm{K} & \mathrm{R} & \mathrm{L} & \mathrm{P} & \mathrm{K} & \mathrm{E} & \mathrm{Y} & \mathrm{K} & \mathrm{V} & \mathrm{L} & \mathrm{V} & \mathrm{N} & \mathrm{T} & \mathrm{A} & \mathrm{I} & \mathrm{T} & \mathrm{N} & \mathrm{L} & \mathrm{P} & \mathrm{R} & \mathrm{F} & 629\end{array}$ ataaattacaagaagaaagagtaagcaagttataatactcaaaatatattgtaagtctaagettattataaggtaatttaaaat 2074 $\begin{array}{llllllllllllllll}\text { I } & N & \text { Y } & \text { K } & \text { K } & \text { E } & \text { R } & \text { V } & \text { S } & \text { K } & \text { L } & -\end{array}$ attaaatgactaggtactgaaaaaaaаaаaаaаaаaаaаaаaаaаaаaаaаaаaаaаaаaаaаaаaаaаaаaаaаaаaаaаaаaаa

Fig. 1. cDNA sequence and deduced amino acid sequence of BmARM-like. The start and termination codons are denoted in the black frame. The functional domains of BmARM-like protein are underlined.

(KOB71817.1), Athalia rosae (XP 012263420.1), Aedes aegypti (XP_001650042.1), Culex quinquefasciatus (XP_001843480.1), Anopheles gambiae (XP_319205.3),
Anopheles sinensis (KFB52334.1), and Habropoda laboriosa (KOC68595.1). Comparison of the BmARMlike amino acid sequence with the published sequences 
of ARM-repeat proteins from others species showed that BmARM-like protein shared $69.2 \%$ sequence homology with both Papilio machaon and Papilio xuthus, 67.6\% with Amyelois transitella, 66.7\% with Plutella xylostella, $66.2 \%$ with Danaus plexippus, $65.7 \%$ with Operophtera brumata and more than $32 \%$ with other species (Fig. 2).

To better elucidate the evolutionary relationships between BmARM-like protein and other sequenced proteins, the whole sequence of BmARM-like and other species was used to determine the evolutionary relationships. A phylogenetic tree consisting of BmARMlike protein and 13 other homologs was constructed. These proteins were clearly classified into three groups: Lepidoptera, Hymenoptera, and Diptera. BmARM-like

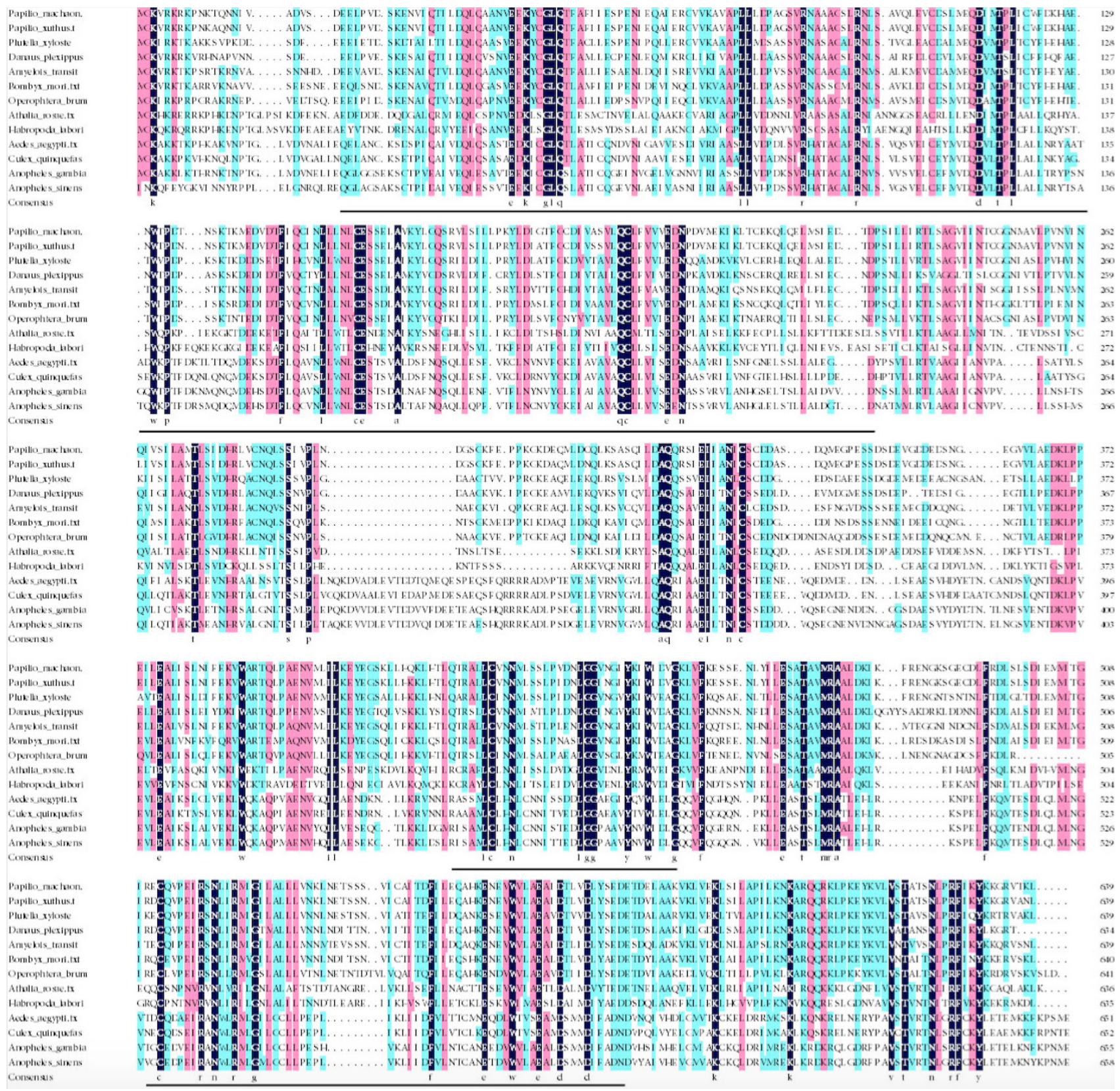

Fig. 2. Sequence comparisons of BmARM-like and its homologs. Identical amino acids are highlighted in mazarine, and the positive amino acids are highlighted in pink and wathet. The functional domains of BmARM-like protein are underlined. 
protein and its homologs from 6 other insects, including Operophtera brumata, Amyelois transitella, Plutella xylostella, Danaus plexippus, Papilio machaon, and Papilio xuthus were clustered together into a Lepidoptera group. Whereas, Athalia rosae and Habropoda laboriosa were clustered into the Hymenoptera group and Aedes aegypti, Culex quinquefasciatus, Anopheles gambiae and Anopheles sinensis were clustered into the Diptera group (Fig. 3).

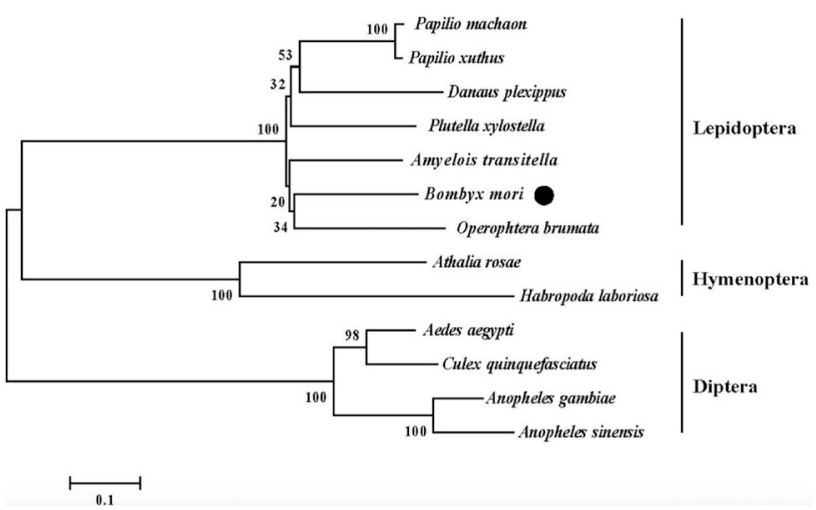

Fig. 3. Phylogenetic analysis of the BmARM-like amino acid sequence using the published sequences of ARMrepeat proteins from other species. The tree was constructed using the neighbor-joining method with pairwise deletion of gaps in MEGA 5. Numbers on nodes indicate bootstrap values from 1000 replicates.

Expression patterns of BmARM-like in different tissues and developmental stages

To elucidate the molecular biological function of BmARM-like, the relative expression levels of BmARMlike mRNA were detected in different silkworm larval tissues and at developmental stages. In different larval tissues, the highest expression of BmARM-like mRNA was observed in hemolymph, followed by testis and ovary, and the lowest expression was observed in the head (Fig. 4A). Comparing developmental stages, the relative high expression levels were observed in $4^{\text {th }}$ instar, moth, and eggs, with decreased expression in $5^{\text {th }}$ instar, and the lowest expression in $1^{\text {st }}$ instar (Fig. 4B). During embryonic development, BmARM-like kept a stable high expression level in the early stages of embryonic development $\left(1^{\text {st }}-6^{\text {th }}\right.$ day of egg development), then gradually decreased until the embryo developed into the head bluing period (the last two days) (Fig. 4C). During pupal development, BmARM-like was up-regulated on the $1^{\text {st }}$ day and then down-regulated over the following three days, with expression again increasing on the $5^{\text {st }}$ day and then decreasing again on the last two days (Fig. 4D). Additionally, BmARM-like showed the highest expression level during the molting stage of $4^{\text {th }}$ instar while other stages of molting show significant low expression as compared to $4^{\text {th }}$ instar (Fig. 4E).

Pattern of BmARM-like expression in different resistant silkworm strains following BmNPV infection

To clarify the relationship between BmARM-like and $\mathrm{BmNPV}$, the expression patterns of BmARM-like mRNA in the midgut and hemolymph of different resistant silkworm strains were analyzed using RT-qPCR before and after BmNPV infection(Fig. 4). In midgut, the highest expression of BmARM-like mRNA was observed in BC9 (nearisogenic line). Following BmNPV infection, BmARMlike was up-regulated in all three strains, while relatively higher expression levels were observed in $\mathrm{BC} 9$ and $\mathrm{A} 35$ (resistant strain) as compared with P50 (susceptible strain) with the up-regulation in A35 being statistically significant (Fig. 4F). In hemolymph, the highest BmARM-like mRNA expression was also observed in the BC9 strain. However, the expression level of BmARM-like was up-regulated in P50, but down-regulated in BC9 and A35 (Fig. 4G).

\section{Polyclonal antibody preparation}

The functional domain of BmARM-like was successfully cloned and ligated into PET-28a to express the fusion proteins (Supplementary Fig. S1). The fusion protein that was confirmed with the antibody to histidine using Western blot was purified using high affinity NiNTA resin (Supplementary Fig. S2) and used to produce polyclonal antibodies. Indirect ELISA was adopted to determine the titer of polyclonal antibodies. The titer of the polyclonal antibodies was greater than 1:384,000 (Supplementary Fig. S3) which met the requirement for later experiments.

The polyclonal antibodies to BmARM-like protein trapped a protein from the total lysates of E.coli with a band approximately $31.1 \mathrm{kDa}$ in size. Additionally, it also crossreacted with the extracts of silkworm tissues, producing a band about $71.2 \mathrm{kDa}$ in size. These results demonstrate the high specificity of the polyclonal antibodies required for later experiments (Fig. 5).

\section{Tissue localization of BmARM-like protein}

To determine the tissue-specific localization of BmARM-like protein, head, midgut, fat body, testis and ovary from the $3^{\text {rd }}$ day of $5^{\text {th }}$ instar were removed and subjected to immunofluorescence analysis with the polyclonal antibodies to BmARM-like protein. As illustrated in Figure 6, BmARM-like protein was found to be distributed uniformly in all selected tissues and did not show significant tissue specificity. 

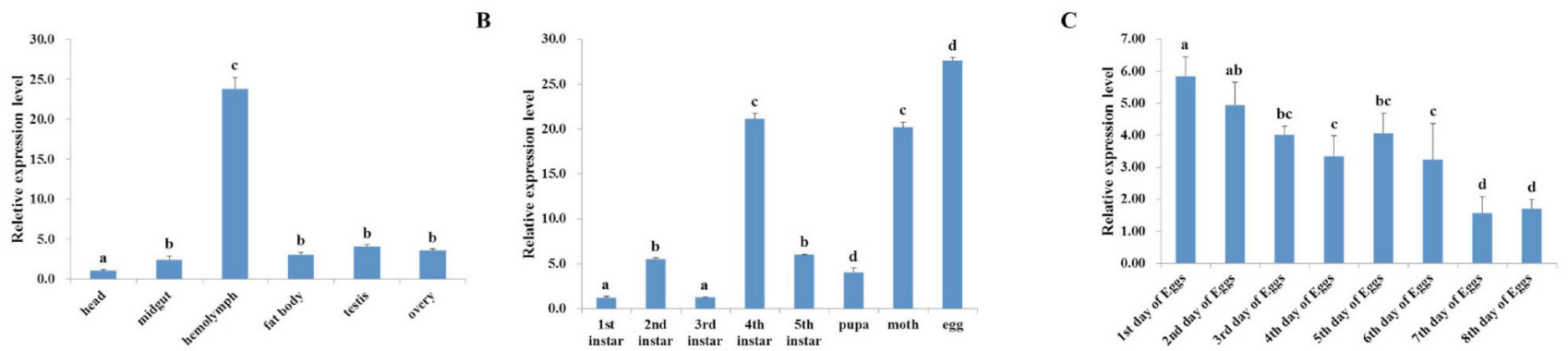

D

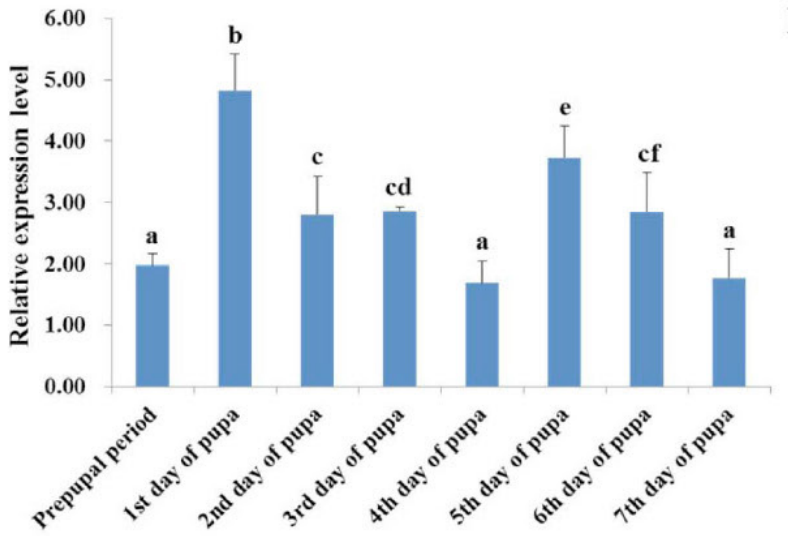

$\mathbf{F}$

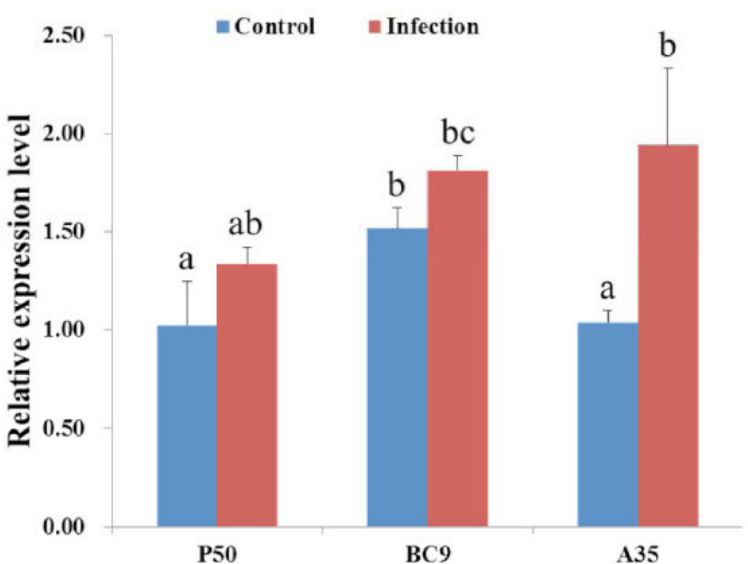

$\mathbf{E}$

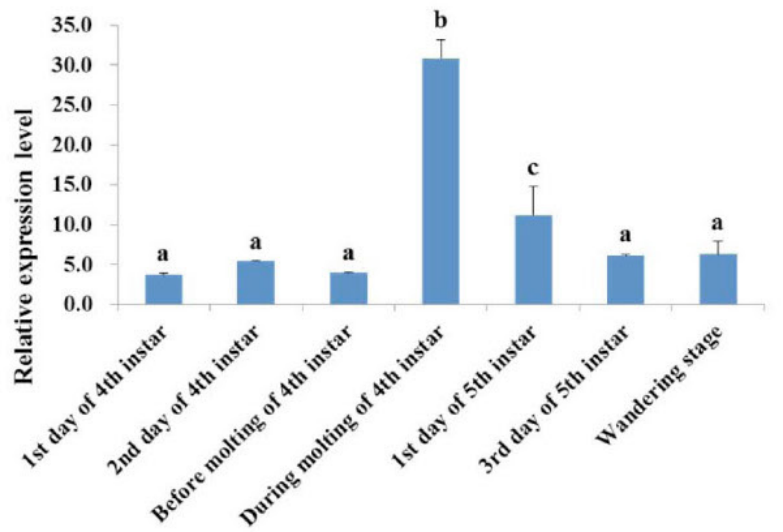

G

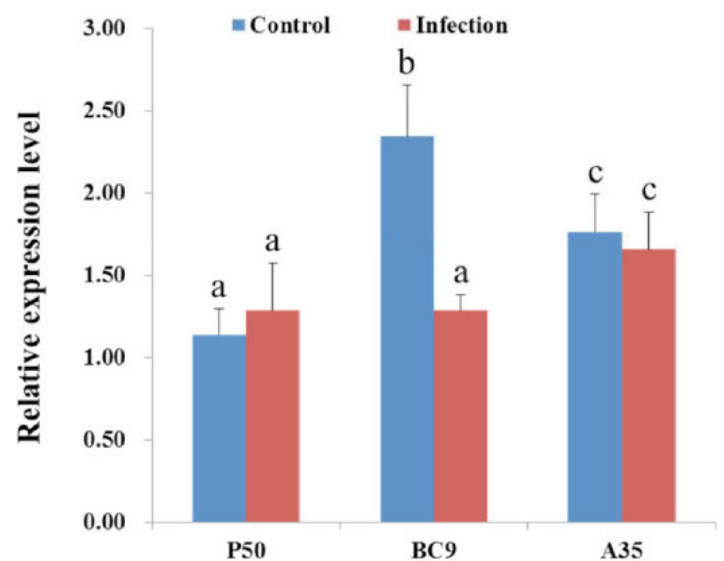

Fig. 4. RT-qPCR analysis of the expression patterns of BmARM-like mRNA. A, B, C, D, and E show the expression patterns of BmARM-like in different silkworm tissues (A), different developmental stages (B), during egg development (C), during pupal development (D), and during molting (E). F and $\mathrm{G}$ show the expression patterns of BmARM-like in the midgut $(\mathrm{F})$ and hemolymph (G) of different resistant silkworm strains following BmNPV infection. Data was normalized using BmGAPDH and is represented as mean \pm standard error of the mean from three independent experiments. Different letters on the bars indicate statistically significant differences based on ANOVA followed by Tukey's HSD multiple comparison test $(\mathrm{p}<0.05)$.

Expression pattern of BmARM-like protein in the midgut of different silkworm strains following BmNPV infection

Western blot was used to further investigate the expression patterns of BmARM-like protein in the midguts of three different silkworm strains following BmNPV infection. The highest expression level of BmARM-like protein was identified in BC9 (near-isogenic strain) as compared with P50 (susceptible strain) and A359 (resistant strain). In addition, the expression of BmARM-like protein was higher in A35 and BC9 following BmNPV infection as compared with P50 (Fig. 7). The expression patterns of BmARM-like protein in different silkworm strains 
following BmNPV infection were basically consistent with the expression patterns of BmARM-like mRNA in the transcriptome levels (Fig. 4).

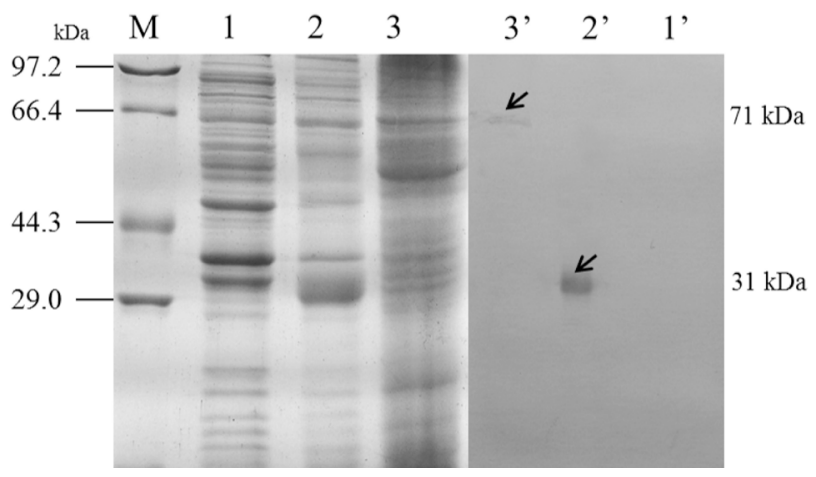

Fig. 5. Western blot analysis of the specificity of polyclonal antibodies to BmARM-like protein. Samples were separated by $12 \%$ SDS-PAGE under reducing conditions. M marker; 1,2,3 SDS-PAGE; 1',2',3' Western blotting; lane 1,1' lysate from E.coli without induction, lane 2,2' lysate from E.coli following induction with IPTG, lane 3,3' total protein extracted from silkworm. $71 \mathrm{kDa}$ band in silkworm and $31.1 \mathrm{kDa}$ band in E.coli were correspond to BmARM-like protein.

\section{DISCUSSION}

In this study, the molecular characterization and functional analysis of a novel silkworm gene, BmARM-like, was described. As far as we know, this is the first report of tissue-specific expression and subcellular localization of BmARM-like in silkworms.

Venkiteswaran et al. (2000) reported that VE-cadherin and the armadillo family protein plakoglobin regulated vascular endothelial permeability and growth. In this study, BmARM-like protein was observed in all selected tissues, but the highest expression of BmARM-like mRNA was found in hemolymph (Fig. 4A). Therefore, we speculated that BmARM-like protein is related to silkworm hemocoel endothelial permeability and growth.

Some reports have shown that ARM repeat-containing proteins play an important role in silkworm growth process (Xiao et al., 2001). In this study, BmARM-like showed significantly high expression in $4^{\text {th }}$ instar, moth, and eggs (Fig. 4B). Additionally, BmARM-like showed relatively high expression levels on the $1^{\text {st }}$ day and $5^{\text {th }}$ day of pupa, and down-regulation within the last few days of this stage (Fig. 4D). These results indicate its role in the growth and development processes of silkworms.

It has been reported that armadillo motif-containing protein possesses a developmentally regulated function during mouse embryonic development (Smith et al., 2005). Knockdown of armadillo motifs containing KPNA7 in the early embryo of silkworm resulted in a decreased
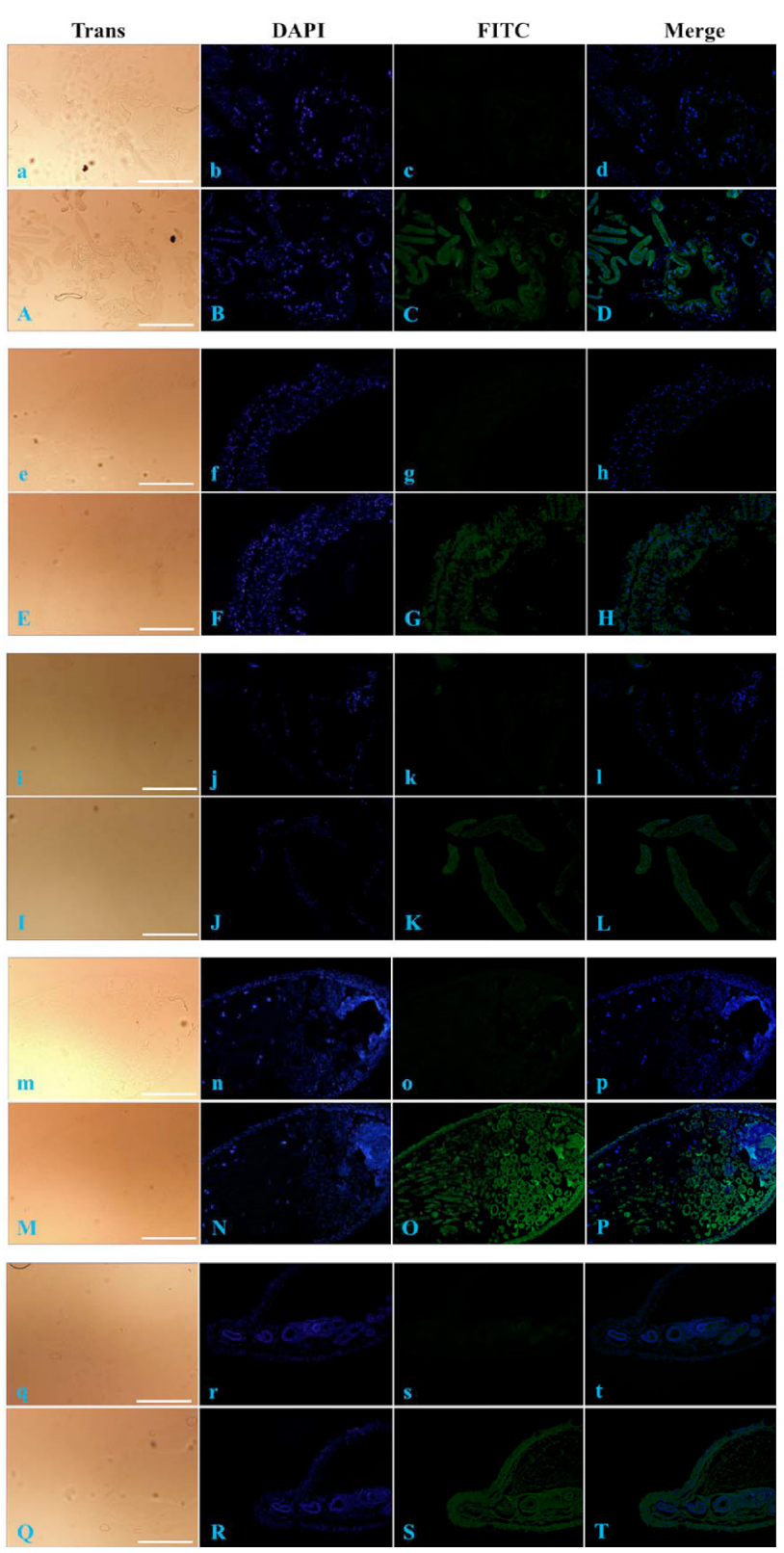

Fig. 6. Immunofluorescence analysis of BmARM-like protein distribution in different silkworm tissues. a-t, negative controls for $\mathrm{A}-\mathrm{T}$, respectively. $\mathrm{a}-\mathrm{d}$ and $\mathrm{A}-\mathrm{D}$, head; $\mathrm{e}-\mathrm{h}$ and $\mathrm{E}-\mathrm{H}$, midgut; $\mathrm{i}-\mathrm{l}$ and $\mathrm{I}-\mathrm{L}$, fat body; $\mathrm{m}-\mathrm{p}$ and $\mathrm{M}-\mathrm{P}$, testis; $\mathrm{q}-\mathrm{t}$ and $\mathrm{Q}-\mathrm{T}$, ovary. Trans (white), optical transmission; DAPI (blue), nuclear staining; FITC (green), BmARM-like protein staining; Merge, merged images for DAPI and FITC. Scale bars $=200 \mu \mathrm{m}$. 


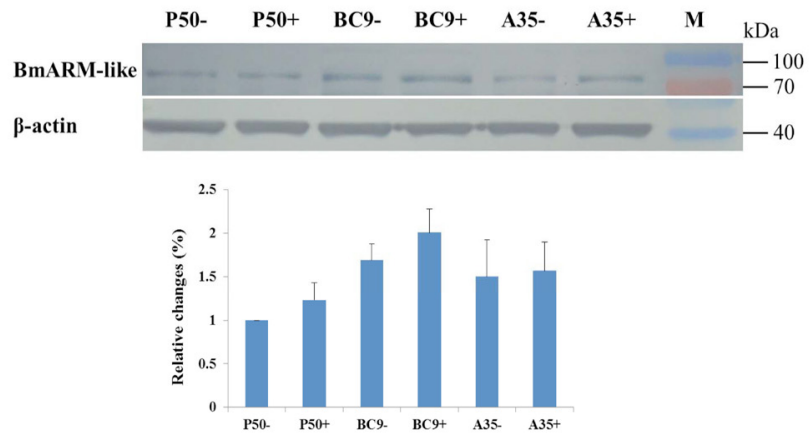

Fig. 7. Representative western blot analysis of the expression of BmARM-like protein in the midguts of different silkworm strains following BmNPV infection. $\beta$-actin was used as a loading control. $M$, marker. Data shown are representative of three independent experiments.

proportion of embryos developing to the blastocyst stage (Shen et al., 2009). In this study, we observed a consistently high expression of BmARM-like in silkworm eggs and during the early embryonic developmental stages (Fig. 4B, C); therefore, we speculated that BmARM-like was involved in regulating embryonic development during the early developmental stages of silkworm embryo.

Insect metamorphosis is triggered by a pulse of steroid hormones, which can regulate the expression of target genes in the body and thus orchestrate drastic biological changes (Niwa and Niwa, 2016). In the silkworm larvae molting stage, the highest expression of BmARM-like was observed in the $4^{\text {th }}$ instar (Fig. 4E), indicating that the expression of BmARM-like was potentially regulated by molting hormones.

Silencing of sterile alpha and armadillo motifcontaining (SARM) protein in Litopenaeus vannamei using dsRNA-mediated RNA interference increased the expression of Penaeidins and antilipopolysaccharide factors and increased the mortality rate after Vibrio alginolyticus infection (Wang et al., 2013). Liu et al. (2014) reported that the increased SARM expression could repress respiratory syncytial virus (RSV) immunopathology caused by deregulation of the toll-like receptor-mediated immune response. In this study, relatively high expression level of BmARM-like were observed in the midgut of $\mathrm{BC} 9$ (nearisogenic line) following BmNPV infection as compared to P50 (susceptible strain), which was also further validated in A35 (resistant strain). Specifically, the up-regulation of BmARM-like in A35 was statistically significant following BmNPV infection (Figs. 4F, 7). These results indicated that BmARM-like was potentially involved in activating the silkworm immune response in an attempt to repress
BmNPV infection. In hemolymph, the expression levels of BmARM-like were up-regulated in P50 but down-regulated in BC9 and A35 (Fig. 4G), which might be due to the activation of the host immune system to suppress the virus infection.

\section{ACKNOWLEDGEMENTS}

This work was supported by the National Natural Science Foundation of China [31472148] and Seed Engineering Fund of Anhui Academy of Agricultural Sciences [16D0608].

\section{Conflict of interest statement}

The authors declare that there is no conflict of interest with any one about this manuscript.

\section{Supplementary Material}

There is supplementary material associated with this article. Access the material online at: http://dx.doi. org/10.17582/journal.pjz/2017.49.6.2181.2191

\section{REFERENCES}

Aberle, H., Butz, S., Stappert, J., Weissig, H., Kemler, R. and Hoschuetzky, H., 1994. Assembly of the cadherin-catenin complex in vitro with recombinant proteins. J. Cell Sci., 107: 3655-3663.

Behrens, J., von Kries, J.P., Kuhl, M., Bruhn, L., Wedlich, D., Grosschedl, R. and Birchmeier, W., 1996. Functional interaction of beta-catenin with the transcription factor LEF-1. Nature, 382: 638642. https://doi.org/10.1038/382638a0

Bradford, M.M., 1976. A rapid and sensitive method for the quantitation of microgram quantities of protein utilizing the principle of protein-dye binding. Anal. Biochem., 72: 248-254. https://doi. org/10.1016/0003-2697(76)90527-3

Brembeck, F.H., Rosario, M. and Birchmeier, W., 2006. Balancing cell adhesion and Wnt signaling, the key role of beta-catenin. Curr. Opin. Genet. Dev., 16: 51-59. https://doi.org/10.1016/j.gde.2005.12.007

Choi, H.J. and Weis, W.I., 2005. Structure of the armadillo repeat domain of plakophilin 1. J. mol. Biol., 346: 367-376. https://doi.org/10.1016/j. jmb.2004.11.048

Coates, J.C., 2003. Armadillo repeat proteins: beyond the animal kingdom. Trends Cell Biol., 13: 463-471. https://doi.org/10.1016/S0962-8924(03)00167-3

Coates, J.C., Laplaze, L. and Haseloff, J., 2006. Armadillo-related proteins promote lateral root 
development in Arabidopsis. Proc. natl. Acad. Sci. U.S.A., 103: 1621-1626. https://doi.org/10.1073/ pnas.0507575103

Couillault, C., Pujol, N., Reboul, J., Sabatier, L., Guichou, J.F., Kohara, Y. and Ewbank, J.J., 2004. TLR-independent control of innate immunity in Caenorhabditis elegans by the TIR domain adaptor protein TIR-1, an ortholog of human SARM. Nat. Immunol., 5: 488-494. https://doi.org/10.1038/ ni1060

Dhawan, S. and Gopinathan, K.P., 2004. Molecular cloning and expression pattern of an armadillo homologue from the mulberry silkworm Bombyx mori. Gene Expr. Patter, 4: 15-23. https://doi. org/10.1016/j.modgep.2003.08.001

Huber, A.H., Nelson, W.J. and Weis, W.I., 1997. Threedimensional structure of the armadillo repeat region of beta-catenin. Cell, 90: 871-882. https:// doi.org/10.1016/S0092-8674(00)80352-9

Kemler, R., 1993. From cadherins to catenins: cytoplasmic protein interactions and regulation of cell adhesion. Trends Genet., 9: 317-321. https:// doi.org/10.1016/0168-9525(93)90250-L

Kidd, A.R., 3rd, Miskowski, J.A., Siegfried, K.R., Sawa, H. and Kimble, J., 2005. A beta-catenin identified by functional rather than sequence criteria and its role in Wnt/MAPK signaling. Cell, 121: 761-772. https://doi.org/10.1016/j.cell.2005.03.029

Liu, J., Phillips, B.T., Amaya, M.F., Kimble, J. and Xu, W., 2008. The C. elegans SYS-1 protein is a bona fide beta-catenin. Dev. Cell, 14: 751-761. https:// doi.org/10.1016/j.devcel.2008.02.015

Liu, T.T., Zang, N., Zhou, N., Li, W., Xie, X.H., Deng, Y., Ren, L., Long, X.R., Li, S.M., Zhou, L.L., Zhao, X.D., Tu, W.W., Wang, L.J., Tan, B. and Liu, E.M., 2014. Resveratrol inhibits the TRIF-dependent pathway by upregulating sterile alpha and armadillo motif protein, contributing to anti-inflammatory effects after respiratory syncytial virus infection. J. Virol., 88: 4229-4236. https://doi.org/10.1128/ JVI.03637-13

Livak, K.J. and Schmittgen, T.D., 2001. Analysis of relative gene expression data using realtime quantitative PCR and the $2^{-\triangle \Delta C T}$ method. Methods, 25: 402-408. https://doi.org/10.1006/ meth.2001.1262

MacDonald, B.T., Tamai, K. and He, X., 2009. Wnt/ beta-catenin signaling: components, mechanisms, and diseases. Dev. Cell, 17: 9-26. https://doi. org/10.1016/j.devcel.2009.06.016

McCrea, P.D., Turck, C.W. and Gumbiner, B., 1991.
A homolog of the armadillo protein in Drosophila (plakoglobin) associated with E-cadherin. Science, 254: 1359-1361. https://doi.org/10.1126/ science. 1962194

Mosimann, C., Hausmann, G. and Basler, K., 2006. Parafibromin/hyrax activates Wnt/Wg target gene transcription by direct association with betacatenin/armadillo. Cell, 125: 327-341. https://doi. org/10.1016/j.cell.2006.01.053

Ngo, Q.A., Baroux, C., Guthorl, D., Mozerov, P., Collinge, M.A., Sundaresan, V. and Grossniklaus, U., 2012. The armadillo repeat gene ZAK IXIK promotes Arabidopsis early embryo and endosperm development through a distinctive gametophytic maternal effect. Pl. Cell, 24: 4026-4043. https:// doi.org/10.1105/tpc.112.102384

Niwa, Y.S. and Niwa, R., 2016. Transcriptional regulation of insect steroid hormone biosynthesis and its role in controlling timing of molting and metamorphosis. Dev. Growth Differ., 58: 94-105. https://doi.org/10.1111/dgd.12248

Noordermeer, J., Klingensmith, J., Perrimon, N. and Nusse, R., 1994. Dishevelled and armadillo act in the wingless signalling pathway in Drosophila. Nature, 367: 80-83. https://doi.org/10.1038/367080a0

Ozawa, M., Baribault, H. and Kemler, R., 1989. The cytoplasmic domain of the cell adhesion molecule uvomorulin associates with three independent proteins structurally related in different species. EMBO J., 8: 1711-1717.

Peifer, M., Berg, S. and Reynolds, A.B., 1994. A repeating amino acid motif shared by proteins with diverse cellular roles. Cell, 76: 789-791. https://doi. org/10.1016/0092-8674(94)90353-0

Rahman, M.M. and Gopinathan, K.P., 2004. Systemic and in vitro infection process of Bombyx mori nucleopolyhedrovirus. Virus Res., 101: 109-118. https://doi.org/10.1016/j.virusres.2003.12.027

Rhee, Y., An, J., Park, S., Kim, S., Kim, Y., Lee, E. and Lim, S., 2006. Identification and validation on the relationship of anabolic effect of parathyroid hormone with Wnt/beta-catenin canonical pathway. J. Bone Miner Res., 21: S322-S322.

Schwede, T., Kopp, J., Guex, N. and Peitsch, M.C., 2003. SWISS-MODEL: an automated protein homology-modeling server. Nucl. Acids Res., 31: 3381-3385. https://doi.org/10.1093/nar/gkg520

Shen, Y.F., Zhang, T.C., Chen, J.Q., Lv, Z.B., Chen, J., Wang, D., Nie, Z.M., He, P.A., Wang, J., Zheng, Q.L., Sheng, Q., Wu, X.F. and Zhang, Y.Z., 2009. Molecular characterization and tissue localization 
of an F-Box only protein from silkworm, Bombyx mori. Comp. Funct. Genom., 1: 416040.

Smith, C.A., McClive, P.J. and Sinclair, A.H., 2005. Temporal and spatial expression profile of the novel armadillo-related gene, Alex2, during testicular differentiation in the mouse embryo. Dev. Dyn., 233: 188-193.

Striegl, H., Andrade-Navarro, M.A. and Heinemann, U., 2010. Armadillo motifs involved in vesicular transport. PLoS One., 5: e8991. https://doi. org/10.1371/journal.pone.0008991

Tewari, R., Bailes, E., Bunting, K.A. and Coates, J.C., 2010. Armadillo-repeat protein functions: questions for little creatures. Trends Cell Biol., 20: 470-481. https://doi.org/10.1016/j.tcb.2010.05.003

Tolwinski, N.S. and Wieschaus, E., 2001. Armadillo nuclear import is regulated by cytoplasmic anchor Axin and nuclear anchor dTCF/Pan. Development, 128: $2107-2117$.

Venkiteswaran, K., Summers, S., Calkins, C.C. and Kowalczyk, A.P., 2000. VE-cadherin and the armadillo family protein plakoglobin regulate vascular endothelial permeability and growth. Mol. Biol. Cell, 11: 552a-553a.

Wang, P.H., Gu, Z.H., Wan, D.H., Zhu, W.B., Qiu, W., Weng, S.P., Yu, X.Q. and He, J.G., 2013. Litopenaeus vannamei sterile-alpha and armadillo motif containing protein (LvSARM) is involved in regulation of penaeidins and antilipopolysaccharide factors. PLoS One, 8: e52088. https://doi. org/10.1371/journal.pone.0052088

Wang, X.Y., Yu, H.Z., Geng, L., Xu, J.P., Yu, D., Zhang, S.Z., Ma, Y. and Fei, D.Q., 2016. Comparative transcriptome analysis of Bombyx mori (Lepidoptera) larval midgut response to BmNPV in susceptible and near-isogenic resistant strains. PLoS One, 11: e0155341.

Xiao, K., Venkiteswaran, K., Calkins, C., Summers, S. and Kowalczyk, A., 2001. Regulation of endothelial barrier function and growth by the armadillo family proteins plakoglobin and beta-catenin. J. Invest. Dermatol., 117: 390-390.

Zhang, Z.Y., Lin, K., Gao, L., Chen, L.Y., Shi, X.S. and Wu, G., 2011. Crystal structure of the armadillo repeat domain of adenomatous polyposis coli which reveals its inherent flexibility. Biochem. biophys. Res. Commun., 412: 732-736. https://doi. org/10.1016/j.bbrc.2011.08.044

Zhao, G., Li, G., Schindelin, H. and Lennarz, W.J., 2009. An armadillo motif in Ufd 3 interacts with Cdc48 and is involved in ubiquitin homeostasis and protein degradation. Proc. natl. Acad. Sci. U.S.A., 106: 16197-16202. https://doi.org/10.1073/ pnas.0908321106 